\title{
Rituell omskjæring av guttebarn - et etisk og juridisk dilemma \\ Kommentar til Peter Gardes artikkel: \\ «Omskærelse, forbrydelse eller gudsdyrkelse»
}

\section{Sturla J. Stålsett ${ }^{1}$}

Rituell omskjæring av guttebarn reiser vanskelige prinsipielle spørsmål. Spørsmålene er politiske, etiske og juridiske. Men også medisinske og religionsfaglige. Er det riktig å betegne inngrepet som en form for skade eller krenkelse? Hvor går grensen mellom barns selvbestemmelse, foreldrerett og religionsfrihet? Utgjør den religiøse begrunnelsen for inngrepet en relevant juridisk eller etisk forskjell? Er det relevante forskjeller på irreversibiliteten i dette inngrepet og andre varige spor foreldres valg nødvendigvis setter på sine barns kroppslige og sjelelige utvikling? Hvilken rolle spiller antisemittiske holdninger i historie og samtid i debatten om de ulike vurderingene av den medisinske risikoen ved inngrepet?

Det er viktig at disse spørsmålene diskuteres offentlig. Det er imidlertid synd at debatten ofte skjemmes av høy temperatur og lav grad av saklighet. Peter Gardes artikkel «Omskærelse, forbrydelse eller gudsdyrkelse. Foredrag i Rødovre Præstekonvent» (NTfK 1/2014, s. 1-36) er intet unntak i så måte. Det vil jeg komme tilbake til.

Garde oppgir at pr. i dag er nesten en av fire menn i verden omskåret (s.4). Denne fjerdepart av alle menn hevder han er utsatt for et overgrep når de er omskårne som barn. Han ønsker å forby praksisen, og straffeforfølge foreldre som lar sine guttebarn omskjære. Kravet til begrunnelse for en slik drastisk endring av lovverket må følgelig være høy, og konsekvensene gjennomtenkt.

\section{Barns beste og religionsfriheten}

Så vel barns selvstendige religionsfrihet som det tungtveiende prinsippet om barn beste i barnekonvensjonen (se artikkel 14) berettiger en kritisk drøftelse av praksisen med omskjæring av guttebarn. Derfor vil jeg kortfattet presentere grunnene til at jeg selv og flertallet i det norske utvalget jeg ledet, konkluderte annerledes enn Garde i dette spørsmålet.

Det regjeringsoppnevnte utvalget som i januar 2013 overleverte utredningen «Det livssynsåpne samfunn. En helhetlig tros- og livssynspolitikk» (NOU 
2013:1), ${ }^{2}$ hadde i oppdrag å komme med anbefalinger om en mer helhetlig trosog livssynspolitikk, og presenterer åtte prinsipper for dette (kap. 9, s.106-112). Utvalget vurderer også utfra disse prinsippene en del sentrale kontroversspørsmål i tros- og livssynspolitikken, deriblant rituell omskjæring av guttebarn (kap. 19.5.2, s. 246-253.)

Hensynet til barns beste er og bør være det sentrale anliggendet - også i møte med tros- og livssynsfriheten. Samtidig er det avgjørende å fastholde foreldrenes rett og plikt til å sørge for barnas beste. Det vil også i mange tilfelle si å avgjøre hva dette består i, der det råder berettiget tvil. Når det gjelder tros- og livssynsspørsmål er dette en krevende avveining. De relevante rettslige konvensjonene, som Den europeiske menneskerettighetskonvensjonen (EMK) første tilleggsprotokoll artikkel 2, FN-konvensjonen om sivile og politiske rettigheter (SP) artikkel $18 \mathrm{nr}$. 4, samt FNs barnekonvensjon artikkel 18, vektlegger foreldreretten noe ulikt på dette området. Nasjonal lovgivning varierer også. Barn har selvstendig religionsfrihet, men når inntrer den i praksis?

Foreldre påvirker sine barn på irreversible måter, både kroppslig og psykisk, positivt og negativt. Barn utsettes daglig for helseskader og unødig risiko på grunn av foreldrenes handlinger, uten at myndighetene griper inn. Foreldrenes røyking gir mange barn betydelige, ofte livsvarige, astmaplager. Alkohol og rus i hjemmene har betydelige og dramatiske skadevirkninger for barn, uten at det tas seriøst til orde for et forbud mot bruk av rusmidler i barns nærhet, eller under graviditet. En del vaksiner har usikker effekt, og risiko for bivirkninger. Foreldrene må avgjøre hvorvidt belastningen er akseptabel.

Dette er reelle dilemmaer. Forholdet mellom barn og foreldre, frihet og ansvar veies opp mot hva som må vurderes å være generelt skadelig, og videre uopprettelig eller irreversibelt skadelig. Selv der det er opplagt at en handlemåte påfører barn skade (jfr. rusbruk), er det likevel ikke sikkert at bruk av lov og straff er veien å gå for å hindre skaden.

Når det gjelder rituell omskjæring av guttebarn, er det første spørsmålet som må besvares hvorvidt inngrepet bør betegnes som en skade eller en krenkelse. En nøktern lesning av det medisinskfaglige votum leder fjorten av femten utvalgsmedlemmer til konklusjonen at dette ikke er en rimelig betegnelse. Utvalget mener det ikke har ekspertise til å overprøve det medisinske skjønn som fastholder at inngrepet ikke er å anse som et uakseptabelt risikabelt eller smertefullt, når det utføres på forsvarlig vis.

Dermed trer tre andre resonnementer inn som blir viktige for utvalgets flertall.

Det første resonnementet er konsekvensetisk: Selv om inngrepet skulle bli forbudt i ett eller flere land, er det likevel lite trolig at praksisen vil opphøre. Den 
er for dypt forankret i menneskers religiøse overbevisninger til det. Det en så vil oppnå med et forbud, i tillegg til å fordømme jødedom og islam på dette punktet, er å jage praksisen ut av landet eller eventuelt tvinge den under jorda. Det vil sannsynligvis øke helserisikoen for guttebarna, ikke senke den. Derfor konkluderer utvalgets flertall med at det er «... tale om en religiøs og kulturell tradisjon som det er liten grunn til å tro vil forsvinne ved et forbud. Hensynet til barna må da tilsi at man krever at denne praksisen finner sted i mest mulig betryggende former» (NOU 2013:3, s. 253).

Det andre resonnementet er at dette er en praksis som, selv om en måtte ønske at den skulle opphøre eller utsettes, er sammenlignbar med mange andre forhold som må overlates til det frihets- og ansvarsrom som finnes mellom foresatte/foreldre og deres barn. Jeg har nevnt bruk av alkohol eller tobakk i barns nærhet. Dette er langt mer skadelige forhold, som det sannsynligvis vil være lite rom for å forby - blant annet av den enkle grunn at majoriteten da ville «rammes» på en helt annen måte enn ved et forbud mot en praksis som kun minoriteter opprettholder. Majoriteten ville ventelig oppfattet et slikt forbud som en utidig frihets- $0 g$ ansvarsberøvelse.

Det tredje og viktigste resonnementet er knyttet til tros- og ytringsfriheten. Den står som kjent sterkt blant menneskerettighetene. Rituell omskjæring av gutter er en sentral trospraksis for dem det angår, ikke minst for jødene. Her står vi i en situasjon der ulike friheter og rettigheter må veies opp mot hverandre. Utvalget er ikke i tvil om at barns rettigheter må ha forrang for foreldrenes tros- og samvittighetsfrihet, der disse kommer i direkte konflikt. Det gjelder eksempelvis i tilfeller av kritisk behov for blodoverføring. Men, når medisinsk ekspertise kommer til at forsvarlig utført omskjæring av guttebarn ikke innebærer betydelig risiko eller uakseptabel belastning, mener utvalgets flertall at tros- og livssynsfriheten må gjelde. Da bør en respektere foreldrenes religiøse overbevisning som holder den rituelle omskjæringen for å være et viktig gode for barnet ved at det innlemmes i en tro og et fellesskap der det får tilhørighet og en fortolkningsramme rundt sitt liv.

Dette er i korte trekk de viktigste grunner som har ledet til utvalgets flertallskonklusjon. Ett utvalgsmedlem var uenig i denne konklusjonen. Han mener at det bør innføres en aldersgrense for inngrepet, for å ivareta barnets rett til selvbestemmelse. I tråd med utvalgets flertallsvurdering ble partiene på Stortinget i juni 2014 enige om å lovfeste at rituell omskjæring av guttebarn må skje av lege eller ved en leges tilsyn. ${ }^{3}$ Utgiftene til inngrepet vil delvis dekkes av det offentlige, for å sikre at ikke økonomiske forhold hos foreldrene hindrer medisinsk forsvarlighet. 
Debatten omkring dette temaet vil ventelig fortsette med uforminsket styrke. Det er bra. Etiske og juridiske dilemmaer bør diskuteres kontinuerlig, og fokuset på barns rettigheter, helse og oppvekstvilkår må holdes skjerpet. Religion og religiøse praksiser må på ingen måte unnslippe det kritiske søkelyset.

\section{Peter Gardes tendensiøse foredrag}

Men det er å håpe at temperaturen i debatten kan holdes lavere og sakligheten høyere enn det som er tilfelle i Peter Gardes foredrag. Jeg må innrømme at det forundrer meg at tidsskriftet har funnet å kunne publisere det som en faglig artikkel. Jeg finner det retorisk usaklig og tendensiøst, og emosjonelt ladet på grensen til det fordomsfulle.

Det er underlig å lese at forfatteren anser utsagn om Stalin og Hitler «morsomt» (s.3), og at han kaller det «en ufrivillig ironi» at en jødisk overrabbiners navn betyr «slakter» (s.12). Hans inndeling av verden $\mathrm{i}$ «dem» og «oss» preger gjennomgående resonnementene: «Vi» kristne (han snakker til prester), og «de andre» - jødene først og fremst, men også muslimene. Han er i det hele tatt nøye med å oppgi hvorvidt en debattant er jøde eller ei (s.22 o.a. st.), og informerer til og med leseren om når han er «usikker» på dette (s.9). Når det gjelder menneskerettighetenes opprinnelse, tillegger han det (muligens negativ?) betydning at hovedredaktøren, professor René Cassin, «selv var jøde» (s.7).

Det er også besynderlig å lese med hvilken skråsikkerhet forfatteren opererer på faglig bortebane. Det gjelder innenfor religionshistorie og samtidig religionskunnskap, så vel som innen medisin. Den religionshistoriske gjennomgangen er så overfladisk og preget av anekdotisk raljering, at den bare bør betraktes som useriøs. Vi får høre at «jøderne har valgt» spedbarnsalder som tidspunkt for omskjæringen (s.2). Det viser at selv om Garde opplyser leseren om det helt innlysende, nemlig at «den religiøse begrundelse står stærkt hos jøderne» (s.2), gir han ikke selv denne innsikten noen egentlig vekt. Han hevder bare bryskt at rituell omskjærelse «aldrig [er] til gavn for barnet» (s. 19).

Innen medisin overprøver juristen Garde den danske Sundhedsstyrelsens og mange andre instansers medisinfaglige skjønn om at den helsemessige belastningen og risikoen er lav ved omskjæring for gutter dersom den er forsvarlig gjennomført. Og han mer enn antyder at politikere som fester lit til denne vurderingen er feige.

Der Garde er på faglig hjemmebane, er argumentasjonen i hvert fall for denne leser skuffende kortfattet, slik at konklusjonene virker forhastede og forutinntatte. Han begynner den juridiske drøftelsen med å påstå uten videre at det er «åbenbart» at omskjæring av guttebarn må betraktes som en voldelig, straffbar hand- 
ling, som «falder ind under straffelovens $§ 244$ om vold, hvor strafferammen er fængsel indtil 3 år» (s.18).

Var det slik, ville jo saken være opplest og avgjort. Men det er altså ikke slik, verken i Danmark eller så vidt meg bekjent noe annet land på kloden i dag: Rituell omskjæring av guttebarn betraktes ikke som vold eller krenkelse, og straffes ikke. Praksisen anses generelt ikke for å være i strid med Den europeiske menneskerettighetskonvensjonen. Det er faktisk mulig at et forbud, som altså Garde går inn for, ville være i strid med denne konvensjonen. Han drøfter ikke denne muligheten.

Etter min mening gir Garde ingen fyllestgjørende juridisk vurdering av hva som er grunnene til denne iøynefallende diskrepansen. I stedet vil Garde «tænke højt» (s.18), og vi făr hans emosjonelle utbrudd om hvor uhyrlig han mener praksisen er, og påstander om generell politisk unnfallenhet og jødisk/muslimsk påvirkning eller dominans. Slikt bidrar dessverre ikke til en opplyst og saklig debatt.

\section{Noter}

1. Dr.theol., professor diakoni, religion og samfunn, MF - Det teologiske menighetsfakultet, Oslo. Leder av det regjeringsutnevnte utvalget for gjennomgang av tros- og livssynspolitikken i Norge («Stålsettutvalget»), (2010-2013).

2. Se: http://www.regjeringen.no/nb/dep/kud/dok/nouer/2013/nou-2013-1.html?id=711212

3. Se: http://www.nrk.no/norge/stortingspartia-samde-om-omskjering-1.11773379 